\title{
ANOTHER CLINICAL STORY TO TELL
}

\section{Veronika Tomoszková and Maxim Tomoszek}

\section{Centre for Clinical Legal Education, Palacký University in Olomouc, School of Law,}

\section{Czech Republic}

When Stefan H. Krieger presented his keynote speech "Stories Clinicians Tell” in 2012 at Law School of the Palacký University in Olomouc (Palacký Law School), it was the culmination of the Complex Law Teaching conference and very emotional moment for the whole clinical team of Palacký Law School, but we believe also for Professor Krieger himself. His efforts leading to establishing the first live-client clinic in Central Europe at the Palacký Law School in 1996 will always be the cornerstone of the Palacký clinical programme, which was re-started ten years later, in 2006. What is more, the impact of Stefan H. Krieger together with Richard K. Neumann from the Hofstra Law School upon the Palacký Law School's curriculum went beyond the original live-client clinic. Their book Essential Lawyering Skills ${ }^{1}$ which we received in 2005 as a free copy by a chance at a conference on teaching practical skills organized by the CEELI ${ }^{2}$ in Prague served as one of the sources for the introduction of the compulsory Legal Skills Course. Skills courses together with the clinical programme, street-law programme

\footnotetext{
${ }^{1}$ Now in its 5th Edition: Krieger, S.H. (2015) Essential Lawyering Skills: Interviewing, Counseling, Negotiation, and Persuasive Fact Analysis. Aspen Coursebook Series, Wolters Kluwer.

${ }^{2}$ Central and East European Law Initiative Institute
} 
and moot courts are melded into a unique practice-oriented component of the Palacký Law School's curriculum.

The stories told by Stefan H. Krieger are extremely important for understanding the pitfalls and challenges of development of legal clinics in Central Europe, and maybe to some extent also Western Europe. The story of an unsuccessful attempt to transplant some elements of U.S. clinical legal education bears much edification for anyone designing a new clinic anywhere in the world. This also confirms Professor Krieger's claim not to "shy away from identifying our failures, problems, and doubts" and sharing the ways how we coped with them. The much desired re-publication of Stefan H. Krieger's article in the International Journal of Clinical Legal Education is an opportunity for us to provide a third story, depicting the narrative of Palacký clinical programme from yet another perspective, and perhaps making the picture more plastic and complex.

The story of re-development of clinical programme at Palacký Law School shows the importance of institutional memory and perseverance. The Palacký Law School was re-established in 1991 as the first law school in Czechoslovakia based on ideals of democracy and rule of law instead of the Communist ideology which influenced the legal education at the law schools operating at that time. Palacký Law School was supposed to be different, modern and legal clinics were part of this idea from the beginning. But every idea no matter how noble it is including clinical legal education 
needs the right conditions to thrive. And that is exactly the story of Palacký Law School and its failures and successes in clinical legal education.

Professor Krieger's article concludes that the story of Palacký clinical programme well demonstrates the "need for slow, grassroots development of clinics rather than close direction by experts from abroad." We would like not only to confirm that this approach was crucial for sustainability of our clinical programme, but also to add some other important elements. The Palacký Law School needed to develop its own internal human resources, who, by going abroad and gathering experience, would constitute a team capable of adapting foreign models of legal clinics to the specific Czech social, historical and legal context. Even twenty years later the Czech students still do not represent their clients in court, but this by no means precludes operating successful legal clinic and providing high quality legal aid to the local community.

The most important part of Stefan H. Krieger's article is the analysis of how clinicians themselves portray clinical legal education and that they are often prone to making the same mistake that they try to eliminate in students - presenting unsubstantiated beliefs as solid facts. The need for deep, serious inquiry into the outcomes of clinical legal education is certainly one of the worldwide trends in clinical legal education, which experienced clinicians like Professor Krieger helped to establish.

Acknowledging the importance of progress in mapping and collecting data about acquired competences, we would like to add one more line of inquiry, focusing on our students: who they are, what are their needs and how they learn. The current 
generation of students is significantly different from who we were as students or from students we had ten years ago. A question arises, whether the design of legal education has adapted to reflect those changes. At the same time, especially in Central Europe, it is very easy to forget that the students are not the only beneficiaries of clinical legal education - the idea of service learning and providing essential legal aid for the local community allows the university to fulfil its third role and contribute to transformation of students towards socially responsible professionals with teachers as their role models. 